\title{
Tantangan dan Strategi Audit Internal Menghadapi Era New Normal pada saat Pandemi Covid 19 di Akademi Maritim Nusantara
}

\author{
Hari Sucahyowati \\ Akademi Maritim Nusantara, Cilacap \\ harisucahyowati@yahoo.com
}

Diterima 01 Februari 2021, direvisi 08 Februari 2021, diterbitkan 08 Marer 2021

\begin{abstract}
Abstrak
Audit internal memiliki peran penting sebagai garis pertahanan dalam pengelolaan dan pengendalian risiko yang efektif di dalam dan di luar organisasi. Perkembangan dunia pendidikan khususnya pendidikan tinggi menuntut setiap perguruan tinggi untuk selalu menyesuaikan proses bisnisnya. Pandemi Covid 19 tidak hanya dirasakan di Indonesia tetapi juga di seluruh dunia dan merupakan pengalaman baru, dan tiba-tiba karena tidak pernah diduga keadaan ini akan terjadi, sehingga semua organisasi menyesuaikan proses bisnisnya secara tiba-tiba dan tanpa perencanaan. Pandemi Covid 19 harus segera diatasi. Pandemi Covid-19 telah mempengaruhi sebagian besar proses bisnis yang dilakukan oleh QMR (Quality Management Representative) dalam melakukan Audit Internal di perguruan tinggi, sehingga perlu adanya penyesuaian strategi dalam menjalankan aktivitas Internal Audit.
\end{abstract}

Kata Kunci: Tantangan, Strategi, Audit Internal, Covid 19

\begin{abstract}
Internal audit has an important role as a line of defense in effective risk management and control inside and outside the organization. The development of the world of education, especially higher education, requires every university to always adapt its business processes. The Covid 19 pandemic was felt not only in Indonesia but also around the world and was a new experience, and suddenly because it was never expected that this situation would occur, so that all organizations adjust their business processes suddenly and without planning. The Covid 19 pandemic must be addressed as soon as possible. The Covid-19 pandemic has affected most of the business processes carried out by QMR (Quality Management Representative) in conducting Internal Audit in universities, so it is necessary to adjust the strategy in carrying out Internal Audit activities.
\end{abstract}

Keywords : Challenges, Strategy, Internal Audit, Covid 19

\section{Pendahuluan}

Tahapan audit internal dimulai berturut-turut dengan perencanaan, pelaksanaan, evaluasi, control atau pendendalian, peningkatan, sehingga kegiatan di setiap unit organisasi yang diawali dengan perencanaan yang kemudian dilaksanakan dan dilanjutkan dengan dilakukannya audit internal sebagai sebuah proses evaluasi yang akan mengukur kesesuaian antara perencanaan dan pelaksanaan dengan standar yang tekah di tetapkan, di perguruan tinggi proses ini dilakukan secara terus menerus untuk selalu dapat melakukan perbaikan

Audit Internal dilakukan secara berkala atau sesuai kebutuhan Institusi. Audit ini dilakukan oleh orang-orang yang di tunjuk oleh pihak manajemen, dan telah dibekali pelatihan dan 
memiliki pengetahuan yang cukup atas standar perguruan tinggi dengan baik. Team auditor ini sebaiknya mewakili setiap program studi yang ada di perguruan tinggi dan melakukan auditor secara silang. Karena tanggung jawab auditor internal cukup besar, maka wajar apabila diberi insentif sesuai dengan kebijakan masing-masing manajemen perguruan tinggi.

Pelaksanaan Audit internal sebaiknya telah dijadwalkan, sehingg waktu pelaksanannya terjadwal dan juga da kepastian siapakah yang menjadi auditornya dan siapakah yang akan menjadi auditee (area audit), sebelum pelaksanaan audit dilakukan, sebaiknya aditee juga telah diberitahu batasa standar apa yang akan di audit.

Audit Internal setidaknya dilakukan dalam 2 (dua) tahap, yaitu :

1. Auditor melakukan pemeriksaan dokumen yang dimiliki setiap unit dan dokumendokumen lain yang terkait dengan unit yang unit yang di audit.

2. Tahap kunjungnan atau visitasi, yaitu dengan melakukan wawancara dengan auditee dan atau pihak-pihak lain yang berakitan dengan unit kerja yang di audit, kemudian melakukan verifikasi hasil evaluasi yang diperoleh dengan dokumendokumen pendukung yang telah di audit sebelumnya.

Seorang Auditor bukanlah atasan dari autditee, sehingga seorang auditor harus mampu menjadi pendengar yang baik dan bertanya dengan baik tanpa menyinggung perasaan auditee.

Auditor tidak lepas dari nilai-nilai etik, dan harus memiliki profesionalitas, tanpa berpihak, karena auditor tugasnya tidak mencari-cari kesalahan tetapi memberikan masukkan guna perbaikan system yang telah disepakati di dalam organisasi dalam mencapai tujuannya.

\section{Materi dan Metode}

\section{QMR (Quality Management Representative)}

Di dalam perguruan tinggi QMR (Quality Management Representative) adalah representative dari manajemen yang diberi wewenang dan tanggung jawab:

1. Memastikan apakah proses untuk mengimplementasikan sistem manajemen mutu ditetapkan, diimplementasikan dan dipelihara oleh setiap unit di perguruan tinggi.

2. Memberikan report kepada pihak manajemen tentang kinerja setiap unit dalam melaksanakan sistem manajemen mutu dan memberikan masukan meperbaikan yang diperlukan.

3. Memastikan bahwa manajemen pelayanan kepada user/pelanggan khususnya mahasiswa di perguruan tinggi dan masyarakt pada umumnya dijalakan dan dilakukan oleh setiap unit.

4. Melakukan sosialisasi atas kebutuhankebutuhan mahasiswa, kepada seluruh unit pelaksana

Menjadi jembatan informasi dengan pihak luar perguruan tinggi yang berkaitan dengan Sistem Manajemen Mutu.

\section{Audit Internal (AI)}

Penilaian Audit Internal harus dilaksanakan dengan sistematis dan objektif dan dilaksanakan oleh QMR untuk memeriksa dan mengevaluasi apakah pelaksanaan manajemen mutu Perguruan Tinggi telah sesuai dengan standar yang ditetapkan.

Fungsi Audit Internal adalah membantu membantu setiap unit untuk dapat melaksanakan fungsinya secara baik untuk mencapai tujuan Perguruan Tinggi sehingga Audit internal harus mampu meberikan memberikan penilaian yang tidak bias dan menyampaikan rekomendasi yang memiliki nilai tambah bagi suatu Perguruan Tinggi.

Audit Internal di Akademi Maritim Nusantara dilakukan oleh QMR yang memiliki tugas untuk melakukan audit terhadap seluruh unit yang ada di lingkungan Akademi Maritim Nusantara. Seluruh kegiatan Audit Internal harus ditujukan untuk mendukung tercapainya tujuan pengendalian internal. Saat menjalankan tugasnya, Kedudukan QMR Quality Management Representative) dalam perguruan tinggi adlah independen, sehingga dalam melaksanakan tugasnya harus obyektif dan tidak bias.

Beberapa ahli memberikan definisi yang beragam atas Audit Internal, definisi-definisi tersebut intinya memiliki makna yang sama, beberapa pendapat tersebut antara lain:

Internal audit adalah pelaksana audit/auditor yang menjalankan tugas di dalam perusahaan 
yang tugasnya mengetahui pelaksanaan prosedur dan kebijakan yang telah ditentukan oleh manajemen dipatuhi dan menetapkan apakah pengelolaan akan sumber daya/aset organisasi/perusahaan telah dilaksanakan dengan baik, menetapkan seberapa efektif dan efisien dari prosedur kegiatan organisasi/perusahaan dilaksanakan dan menilai efektifitas informasi yang dibuat oleh setiap unit di dalam organisasi/perusahaan [1].

Arti internal audit ialah pemeriksaan yang dijalankan oleh unit audit internal yang dimiliki organisai terhadap laporan keuangan dan laporan akuntansi perusahaan serta melihat apakah setiap unit dalm organiasi patuh akan kebijakan yang ditentukan manajemen, peraturan pemerintah dan ketentuan dari perserikatan profesi [2].

Guy mendefinisikan audit adalah proses untuk mengidentifikasi data dan mengevaluasi bukti dengan sistem yang obyektif dalam rangka memberi penilaian kesesuaian diantara pernyataan dan kriteria yang ditentukan dan kemudian hasil tersebut disampaikan kepada pihak manajemen [3].

Definisi audit internal adalah fungsi penilaian yang dilakasanakan secara independen didalam organisasi untuk melakukan evaluasi terhadap kegiatan/program yang dijalankan [4].

IAA mendefinisikan bahwa internal audit adalah kegiatan yang independen dan obyektif dan juga kegiatan konsultatif yang dibuat untuk meningkatkan nilai dan opersional organisasi/perusahaan [5].

\section{Era New Normal saat Pandemi Covid 19}

New normal merupakan perubahan perilaku setiap individu/organisasi untuk tetap menjalankan aktivitas secara normal dengan ditambah menerapkan protokol kesehatan yang tekah di tetapkan oleh kebijakan pemerintah dan atau badan organisai dunia (seperti WHO) guna mencegah terjadinya penularan Covid-19.

Pandemi COVID-19, dikenal juga sebagai pandemi coronavirus, adalah kelanjutan pandemi dari penyakit coronavirus 2019 (COVID-19) yang disebabkan oleh akut sindrom pernafasan coronavirus 2 (SARS-CoV-2). Virus ini pertama kali teridentifikasi pada bulan Desember 2019 di Propinsi Wuhan, Cina .

\section{Metode Penelitian}

Penelitian ini merupakan penelitian yang mengunakan metode observasi yaitu metode penelitian yang cara mengumpulkan datanya dengan pengamatan langsung. Metode ini digunakan dengan pengamatan terhadap objek penelitian khususnya pada fokus masalah yang di teliti.

\section{Hasil dan Pembahasan}

\section{Tantangan}

Pandemi Covid 19 mengubah banyak hal dalam pelaksanaan dan kegiatan tata kelola di Akademi maritime Nusantara, terutama dalam siklus Perencanaan - Pelaksanaan - Evaluasi Pengendalian - Peningkatan. apalagi kondisi ini berlangsung sangat tiba-tiba dan baru pertama kali terjadi dan dirasakan di Akademi Maritim Nusantara, hamper semua unit pada awalnya gagap dalam mensikapi Pandemi Covid 19, perlu beberapa waktu untuk setiap unit di lingkungan Akademi Maritim Nusantara untuk menyesuaikan dengan kondisi yang ada.

Keadaan itu memaksa setiap unit untuk beradaptasi dengan berbagai penyesuainpenyesuaian terhadap siklus siklus Perencanaan - Pelaksanaan - Evaluasi-Pengendalian Peningkatan, Keadaan tersebut tentu juga berdampak pada kegiatan Audit Internal yang dilakukan oleh QMR.

Singkatnya, Pandemi Covid 19 telah mempengaruhi sebagian besar proses bisnis yang dijalankan oleh seluruh unit di Akademi Maritim Nusantara, sehingga diperperlukan pertimbangan kembali dan penyesuaian siklus Perencanaan Pelaksanaan - Evaluasi - Pengendalian Peningkatan. Demikian juga QMR bahwa Audit Internal harus tetap dilakukan dengan menempuh pendekatan Audit Alternatif dalam kondisi Pandemi Covid 19 ini.

\section{Strategi}

QMR wajib memiliki sense of crisis, bahwa Auidt Internal harus tetap dilaksanakan dalam kondisi apapun, hal ini diperlukan untuk tetap menjamin bahwa semua prosedur dilaksanakan dalam setiap siklus Perencanaan - Pelaksanaan Evaluasi - Pengendalian - Peningkatan. Sehingga dalam pelaksanaannya QMR melakukan beberapa modifikasi kerja dengan

1. Melakukan identifikasi atas area-area berisiko tinggi

2. Melakukan pengawasan intensif terkait potensi risiko kecurangan, 
3. Memastikan apakah sudah dibuat manajemen krisis/crisis management, disaster recovery, business contingency plan, pada setiap unit kerja agar pengelolaan krisis dapat dilakukan secara sistematis,

4. Melakukan kegiatan monitoring terkait kepatuhan dan efektivitas,

5. Meningkatkan peran advice dan insight (konsultansi/advisory) terutama terkait tata kelola, risiko, dan pengendalian;

6. Melaksanakan komunikasi yang intensif diantara tim audit dengan para stakeholders untuk memberikan advisory selama masa pandemi,

7. Melakukan penyesuaian rencana audit internal sesuai dengan situasi dan kondisi masa pandemi covid 19, terutama penyesuaian situasi dan kondisi kebijakan pemerintah baik Pemerintah Pusat, Provinsi maupun Kabupaten.

8. Mengedepankan pemanfaatan teknologi informasi (remote audit) untuk mendukung pelaksanaan audit internal yang cepat dan intensif Pendekatan remote audit internal ini justru memiliki keunggulan, dalam pelaksanaannya yaitu dapat memperluas cakupan pelaksanaan audit, memanfaatkan teknologi untuk memperkuat dokumentasi dan pelaporan tentunya tidak mengesampingkan pertimbangan keamanan dan kerahasiaan dari dokumen-dokumen yang dimiliki Akademi Maritim Nusantara.

Untuk unit kerja yang belum menggunakan teknologi informasi dilakukan dengan memilih dan memilah skala prioritas unit-unit yang akan dilakukan Audit internal, dan apabila dilaksanakan dengan proses tatap muka, maka pelaksanaannya harus tetap mengedepankan protocol kesehatan dan melibatkan Satgas Covid 19 yang telah di bentuk oleh Akademi Maritim Nusantara.

\section{Kesimpulan}

Pandemi Covid 19 mengubah banyak hal dalam pelaksanaan dan kegiatan tata kelola Akademi maritim Nusantara, terutama dalam siklus Perencanaan - Pelaksanaan - Evaluasi Pengendalian - Peningkatan. Pandemi Covid 19 terjadi begitu tiba-tiba dan Akademi Maritim Nusantara (bahkan semua instansi/Organisasi) belum memiliki pengalaman dalam menghadapi pandemi, sehingga memaksa pelaksanaan dan kegiatan tata kelola Akademi Maritim Nusantara untuk melakukan penyesuaian/adaptasi.

QMR wajib memiliki sense of crisis, bahwa Auidt Internal harus tetap dilaksanakan dalam kondisi apapun, dengan berbagai penyesuaian dan strategi, yaitu : melakukan identifikasi areaarea beresiko tinggi, memastikan bahwa telah dibuat manjemen krisi dalam menghadapi pandemi, melakukan monitoring terhadap kepatuhan dan efektifitas manajemen krisis, lebih meningkatkan peran kegiatan konsultatif, meningkatkan komunikasi dengan stakeholders untuk memberikan advisory, penyesuaian pelaksanaan audit internal dengan situasi dan kondisi pandemic, pemanfaatan teknologi informasi dalam pelaksanaan auit internal, identifikasi dan skala prioritas untuk audit internal tatap muka dengan tetap melakukan protocol kesehatan yang ketat dan melibatkan Satgas Covid 19 yang telah dibentuk di Akademi Maritim Nusantara.

\section{Ucapan terima kasih}

Penulis mengucapkan terima kepada AMN atas dukungannya dalam kegiatan ilmiah ini dan menjadi tempat terselenggaranya penelitian.

\section{Daftar Pustaka}

[1] Mulyadi Gajah Mada university, Auditing, Enam. Jakarta: Salemba Empat, 2001.

[2] S. Agoes, "Auditing," Petunjuk Prakt. Pemeriksaan Akuntan oleh Akuntan Publik (Edisi 4). Buku, vol. 1, 2012.

[3] C. W. A. Dan M. Guy and A. J. Winters, Auditing 2, Lima. Jakarta: Erlangga, 2003.

[4] Hiro Tugiman, Pandangan Baru Internal Auditing. Yogyakarta: Kanisius, 2006.

[5] Institut Akuntansi Publik Indonesia, Standar Profesional Akuntan Publik. Jakarta: Salemba Empat, 2011. 